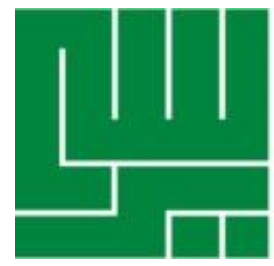

KATA KUNCI

KEYWORDS

ABSTRAK

ABSTRACT

\section{Pengaruh Rasa Kesadaran terhadap Kesejahteraan Psikologis Pada Mahasiswa}

\section{The Influence of Trait Mindfulness toward Psychological Well-Being among University Students}

\author{
Annisa Awaliyah, Ratih Arruum Listiyandini \\ Fakultas Psikologi Universitas YARSI \\ Menara YARSI, Letjend Suprapto Kav.13, Cempaka Putih, Jakarta, 10510, Indonesia \\ annisaawaliyah13@yahoo.co.id, ratih.arruum@gmail.com
}

Mahasiswa, Rasa kesadaran, Kesejahteraan Psikologis

University Student; Trait mindfulness; Psychological well-being

Mahasiswa merupakan individu yang berada dalam masa dewasa transisi sehingga dibutuhkan kesejahteraan psikologis yang optimal dalam menghadapi tugas perkembangannya. Tujuan penelitian ini adalah untuk menganalisis pengaruh dimensi-dimensi rasa kesadaran (mindfulness) terhadap kesejahteraan psikologis pada mahasiswa. Sampel dalam penelitian ini berjumlah 200 orang mahasiswa dari wilayah Jabodetabek, yang dipilih dengan menggunakan teknik convenience sampling. Penelitian menggunakan adaptasi skala Five Facet Mindfulness Quisionare (FFMQ) untuk mengukur rasa kesadaran dan adaptasi skala Scale of Psychological Well-Being (SPWB) untuk mengukur kesejahteraan psikologis. Hasil uji regresi menunjukkan bahwa rasa kesadaran memiliki pengaruh positif dan signifikan terhadap kesejahteraan psikologis, yaitu pada dimensi penerimaan diri dan penguasaan lingkungan. Dimensi rasa kesadaran yang berpengaruh terhadap penerimaan diri adalah mengamati dan tidak menghakimi pengalaman internal, sedangkan dimensi rasa kesadaran yang berpengaruh terhadap penguasaan lingkungan adalah mengamati. Dengan demikian, menjadi penting untuk mahasiswa mengembangkan rasa kesadaran dengan menerima dan mengamati berbagai pengalaman internal maupun eksternal agar lebih mampu menerima diri sendiri dan menguasai tantangan hidup sehari-hari.

University students are individuals who are in the process of transitioning to adulthood. The purpose of this study was to analyze the influence of trait mindfulness dimensions toward psychological wellbeing of university students. The sample in this study were 200 students in the Greater Jakarta area, selected using convenience sampling technique. The study used an adapted version of Five Facet Mindfulness Questionnaire (FFMQ) to measure trait mindfulnesss and Scale of Psychological Well-Being (SPWB) to measure psychological well-being. Results of regression analysis showed that trait mindfulness positively and significantly contributes to dimensions on psychological well-being, namely self-acceptance and environmental mastery. Dimensions of trait mindfulness that have significant roles on self-acceptance are observing and nonjudging of inner experience, while the dimension that influence 
the environmental mastery is observing. Thus, it is imperative for students to develop an attitude of acceptance and observe various internal and external experiences so that they more have self-acceptance and be able to master the challenges faced in everyday life.

\section{PENDAHULUAN}

Mahasiswa merupakan individu yang mengalami masa transisi dari remaja akhir menuju dewasa awal dengan banyak perubahan tugas-tugas dan tanggung jawab yang akan dihadapi. Smolak (1993) mengatakan, mahasiswa tidak dapat dikatakan sebagai remaja, ataupun dewasa. Erikson menyatakan bahwa terdapat perbedaan tugas perkembangan antara remaja akhir dan dewasa awal. Tugas perkembangan remaja akhir lebih mengarah kepada mencari identitas diri atau jati diri, sedangkan tugas perkembangan dewasa awal adalah mencari pasangan hidup, mencari pekerjaan dan terjadinya perubahan peran (Erikson, dalam Papalia, Olds, Feldman, 2008). Oleh karena itu, mahasiswa yang umumnya berusia sekitar 18-25 tahun berada pada masa dewasa transisi (Hurlock, dalam Wibowo, 2010).

Banyaknya perubahan yang terjadi pada saat dewasa transisi menyebabkan individu harus menyesuaikan diri pada perubahan-perubahan tersebut. Tahap dewasa transisi merupakan periode eksplorasi, dimana individu memiliki kesempatan untuk melakukan segala kemungkinan dan juga kesempatan untuk melakukan hal-hal baru dan cara hidup yang berbeda. Dewasa transisi juga tahap dimana individu bukan lagi remaja tetapi mereka belum siap dalam melaksanakan tugas-tugas orang dewasa (Amet, 2000, 2004; Furtenberg et al., 2005 dalam Papalia, Olds, Feldman, 2008).

Sebagai individu yang memasuki masa transisi, mahasiswa menghadapi berbagai konflik. Penelitian Voitkane (2001, dalam www.ispaweb.org) terhadap 607 mahasiswa tahun pertama Universitas Latvia, mendapatkan hasil bahwa 52,6 persen mahasiswa mengalami kesulitan dalam membentuk hubungan baru. Konflik menekan yang dialami mahasiswa lainnya adalah perpisahan dengan orang tua, perpisahan dengan sahabat, perpindahan tempat tinggal, perubahan sistem pendidikan, dan pertentangan sistem penilaian (Pennebaker, Colder, dan Sharp, 1990). Selain itu, mahasiswa juga dihadapkan dengan konflik menekan lainnya seperti konflik hubungan dengan pacar, rendahnya prestasi akademik, konflik dengan orang tua atau teman sebaya (Blau, 1996), dan masalah keuangan (Furr, Conell, Westefeld, dan Jenkins, 2001). Kementerian Kesehatan di Amerika juga mengatakan mahasiswa memiliki banyak sumber stress, antara lain adalah tekanan akademis, perubahan lingkungan dengan tanggung jawab baru, perubahan hubungan sosial, tanggung jawab finansial, menghadapi keputusan yang lebih besar, mengenali identitas dan orientasi seksual, serta mempersiapkan kehidupan setelah kuliah (National Health Ministry, 2006).

Banyaknya konflik dan tugas perkembangan yang dihadapi mahasiswa dapat menyebabkan mahasiswa kesulitan dalam mencapai kesejahteraan psikologis yang optimal (Ismail dan Indrawati, 2013). Kesejahteraan psikologis adalah pencapaian penuh dari potensi psikologis individu dan suatu keadaan ketika individu dapat menerima kekuatan serta diri apa adanya, memiliki tujuan hidup, mengembangkan relasi yang positif dengan orang lain, menjadi pribadi yang mandiri, mampu mengendalikan lingkungan, dan terus bertumbuh secara personal (Ryff, 1995). Kesejahteraan psikologis merupakan kunci bagi individu untuk menjadi sehat secara utuh dan dapat menggunakan potensi yang dimiliki secara maksimal. Kesejahteraan psikologis menurut Ryff (1995) merupakan sesuatu yang multi-dimensional, terdiri dari 
penerimaan diri, hubungan positif dengan orang lain, kemandirian, penguasaan lingkungan, tujuan hidup, dan pertumbuhan pribadi.

Kurang optimalnya kesejahteraan psikologis pada mahasiswa ditunjukkan dari adanya mahasiswa yang belum memiliki tujuan masa depan yang jelas. Sebagai contoh, hasil penelitian Ismail dan Indrawati (2013) menunjukkan bahwa selama menjalani kehidupannya, banyak mahasiswa yang tidak memiliki arah dan target yang jelas, melainkan hanya mengikuti kegiatan mahasiswa pada umumnya. Hariyanto (2010) dan Michael, et.al (2006) juga menjelaskan adanya gejala depresi yang muncul pada mahasiswa. Depresi ditandai dengan adanya kesedihan terus menerus, hilangnya nafsu makan, dan terdapat pandangan negatif mengenai kehidupan yang dijalani. Kondisi-kondisi ini mengindikasikan bahwa mahasiswa perlu untuk lebih memperhatikan kesejahteraan psikologis yang dimilikinya.

Terdapat beberapa penelitian terdahulu yang meneliti faktor-faktor terkait kesejahteraan psikologis pada mahasiswa. Salah satunya penelitian yang dilakukan Fajrina dan Rosiana (2015) tentang kesejahteraan psikologis yang menemukan adanya hubungan positif antara flow dengan kesejahteraan psikologis pada mahasiswa psikologi Universitas Islam Bandung yang aktif berorganisasi. Flow sendiri merupakan kondisi dimana mahasiswa merasa puas oleh reward yang ada dalam diri mereka sehingga mereka ingin mengulangi pengalaman tersebut. Penelitian lainnya yang dilakukan oleh Putri (2012) menyatakan bahwa adanya hubungan positif yang signifikan antara kebersyukuran dan kesejahteraan psikologis pada mahasiswa. Kebersyukuran sendiri adalah perasaan yang menyenangkan dan penuh terima kasih sebagai respon dari penerimaan kebaikan. Penelitian lainnya yang dilakukan oleh Fadli (2012) menyatakan adanya hubungan yang positif antara dukungan sosial dengan kesejahteraan psikologis pada mahasiswa, bahwa dukungan sosial mampu membuat mahasiswa memiliki cara pandang yang positif terhadap suatu masalah atau sesuatu yang sedang dihadapinya. Dari penelitianpenelitian tersebut terdapat indikasi bahwa untuk memiliki kesejahteraan psikologis yang baik, mahasiswa membutuhkan keterlibatan penuh dan menyadari berbagai hal yang ia dapatkan, termasuk dalam mempersepsi adanya hubungan positif dengan orang lain, serta sadar atas sesuatu yang pihak lain berikan. Kondisi kesadaran ini berhubungan dengan konsep psikologis yang disebut sebagai mindfulness (rasa kesadaran).

Brown dan Ryan (2003) mengatakan bahwa rasa kesadaran didasari oleh meningkatnya keadaan sadar terjaga secara berkesinambungan, memonitor keadaan diri dan lingkungan luar, serta adanya perhatian yang memusat sehingga menghasilkan kesadaran penuh akan pengalamannya secara lebih terbuka. Baer, et.al (2006) mendefinisikan rasa kesadaran sebagai meningkatnya kesadaran dengan berfokus pada pengalaman saat ini serta adanya penerimaan tanpa memberikan penilaian.

Rasa kesadaran dapat dilatih dan ditingkatkan melalui serangkaian proses pelatihan. Namun demikian, rasa kesadaran juga dapat dipandang sebagai suatu sifat atau disposisi. Dalam hal ini, individu yang memiliki kecenderungan alamiah atau disposisi untuk mampu menampilkan kesadaran secara utuh dan penuh di dalam berbagai aspek kehidupan dikatakan memiliki rasa kesadaran yang baik. Individu dengan rasa kesadaran yang tinggi, cenderung mampu bersikap sadar utuh dalam berbagai konteks. Rasa kesadaran membantu individu untuk bisa melihat secara lebih dalam hubungan antara pikiran, perasaan, dan aktivitasnya, sehingga makna dan penyebab dari pengalaman dan perilaku disadari sepenuhnya. Pengalaman terbuka dan penerimaan memungkinkan perspektif yang lebih luas akan pikiran dan perasaan, sehingga risiko depresi dapat dikurangi bersama dengan meningkatnya kesadaran 
akan pikiran negatif (Lau dan McMain, 2005; Finucane dan Mercer, 2006).

Beberapa penelitian terdahulu mengungkapkan bahwa rasa kesadaran dapat membantu seseorang untuk dapat memiliki hidup yang lebih sehat dan tidak mudah cemas, tidak mudah depresi, memandang hidup lebih baik, meningkatkan hubungan positif dengan orang lain, meningkatkan harga diri, dan meningkatkan fungsi ketahanan tubuh manusia (Kabat-Zinn dkk dalam West, A.M, 2008). Kajian lainnya yang dilakukan oleh Baer, et al (2006) juga menemukan bahwa rasa kesadaran memiliki hubungan yang signifikan dan positif dengan kesejahteraan psikologis. Dapat dikatakan bahwa tingkat rasa kesadaran merupakan salah satu faktor yang memprediksi perkembangan psikologis yang baik. Melalui rasa kesadaran, individu dapat melihat permasalahan dengan objektif serta sadar dengan apa yang mereka rasakan sehingga membantunya memiliki kesejahteraan psikologis yang baik.

Untuk mengukur hubungan antara rasa kesadaran dan kesejahteraan psikologis secara lebih spesifik, Baer et al (2006) menggunakan skala rasa kesadaran yang bersifat multidimensional. Dimensi pertama, acting with awareness (bertindak secara sadar), yaitu memberikan atensi penuh pada aktivitas yang sedang dilakukan. Dimensi kedua, observing (mengamati), yaitu menyadari atau melibatkan diri dengan pengalaman internal maupun eksternal seperti sensasi, kognisi, dan emosi. Dimensi ketiga, describing (menggambarkan), yaitu kemampuan individu untuk membuat label berbentuk kata-kata mengenai pengalaman internal, seperti perasaan. Dimensi keempat, nonreactivity to inner experience (tidak bersikap reaktif terhadap pengalaman internal), yaitu membiarkan pikiran datang dan pergi tanpa harus terlarut lebih dalam. Dimensi terakhir adalah non-judging of inner experience (tidak menghakimi pengalaman internal), yang dapat diartikan sebagai sikap non-evaluatif atau tidak mengakimi terhadap pikiran-pikiran yang ada dalam diri (Baer et al, 2006). Melalui penelitian tersebut, ditemukan bahwa semua dimensi rasa kesadaran memiliki hubungan yang positif dan signifikan dengan kesejahteraan psikologis (Baer et al., 2006).

Pada konteks kehidupan mahasiswa, rasa kesadaran tentunya juga diharapkan membantu mahasiswa untuk bisa mencapai kesejahteraan psikologis yang optimal. Apabila mahasiswa memiliki rasa kesadaran yang baik, ia akan sadar dan memberikan perhatian penuh tanpa menghakimi terhadap pengalaman di dalam maupun di luar dirinya. Kondisi kesadaran ini diharapkan dapat membantu mahasiswa untuk mengembangkan potensinya, bertahan dalam menghadapi segala tuntutan akademik maupun non-akademik, sehingga dapat mengoptimalkan kesejahteraan psikologis yang dimilikinya.

Di Indonesia, telah terdapat beberapa bahasan mengenai kesejahteraan psikologis maupun rasa kesadaran. Namun demikian, penelitian yang membahas pengaruh rasa kesadaran terhadap kesejahteraan psikologis mahasiswa masih dibutuhkan. Terutama mengingat bahwa mahasiswa masih membutuhkan pencapaian kesejahteraan psikologis yang lebih optimal. Dengan meneliti pengaruh rasa kesadaran terhadap kesejahteraan psikologis, dapat diketahui dimensi-dimensi dari rasa kesadaran yang memiliki peranan dalam peningkatan kesejahteraan psikologis pada mahasiswa. Hasil penelitian nantinya juga dapat dijadikan sebagai literatur pengetahuan bagi mahasiswa untuk dapat mengoptimalkan rasa kesadaran dalam rangka peningkatan kesejahteraan psikologis. Oleh karena itu, penelitian ini bertujuan untuk menganalisis mengenai bagaimana pengaruh dari rasa kesadaran dalam memprediksi kesejahteraan psikologis pada mahasiswa. 


\section{METODE PENELITIAN}

\section{Desain Penelitian}

Penelitian ini menggunakan rancangan asosiatif eksplanatif, karena peneliti ingin melihat pengaruh satu variabel terhadap variabel lainnya, yaitu pengaruh rasa kesadaran terhadap kesejahteraan psikologis pada mahasiswa.

\section{Partisipan Penelitian}

Pada penelitian ini karakteristik sampel yang digunakan adalah 200 mahasiswa laki-laki dan perempuan berusia 18-21 tahun yang berasal dari kampus di Jabodetabek. Teknik pengambilan sampel dalam penelitian ini adalah nonprobability sampling. Berdasarkan pertimbangan, peneliti mengambil sampel hanya berdasarkan kriteria-kriteria yang cukup umum, maka peneliti memutuskan untuk menggunakan teknik convenience sampling.

Jumlah partisipan pada penelitian ini adalah 200 orang, dengan rincian 145 partisipan mengisi kuesioner online dan 55 partisipan mengisi kuesioner tertulis yang dibagikan peneliti. Partisipan adalah mahasiswa yang berusia antara 18-21 tahun dan sedang berkuliah di wilayah Jabodetabek. Mayoritas partisipan penelitian ini adalah mahasiswa suatu universitas swasta di Jakarta.

Partisipan memiliki rerata usia $\mathrm{M}=19,92 \quad(\mathrm{SD}=1), \quad$ mayoritas berjenis kelamin perempuan $(61,5 \%)$, dan berdomisili di wilayah Jakarta sebanyak 73 orang $(36,5 \%)$. Jika ditinjau dari uang saku perbulan, sebagian besar berkisar antara Rp.1.000.001-Rp.1.500.000 sebanyak 66 orang $(33 \%)$ serta penghasilan orang tua >Rp. $\quad 7.000 .000$ sebanyak 79 orang $(39,5 \%)$. Mayoritas partisipan berstatuskan orang tua menikah sebanyak 189 orang (94,5\%) dengan pekerjaan Ayah seorang PNS sebanyak 66 orang $(33 \%)$ dan pekerjaan Ibu seorang ibu rumah tangga sebanyak 94 orang (47\%). Didapatkan juga sebagian besar pendidikan Ayah (36\%) dan pendidikan Ibu (42,5\%) adalah SMA. Selain itu, mayoritas partisipan juga tidak pernah mengikuti meditasi sebanyak 181 orang $(90,5 \%)$. Mayoritas partisipan juga mengikuti organisasi sebanyak 102 orang $(51 \%)$ dan mayoritas partisipan berada pada tingkat 3 sebanyak 62 orang $(31 \%)$.

\section{Hipotesis Penelitian}

Terdapat pengaruh dari dimensi-dimensi rasa kesadaran terhadap kesejahteraan psikologis pada mahasiswa.

\section{Instrumen Penelitian}

Dalam penelitian ini instrumen penelitian terdiri dari dua alat ukur utama, yaitu skala rasa kesadaran dan skala kesejahteraan psikologis. Kedua alat ukur yang digunakan berupa kuesioner. Kuesioner merupakan teknik pengumpulan data yang dilakukan dengan cara memberi seperangkat pertanyaan atau pernyataan tertulis kepada partisipan untuk dijawab (Sugiyono, 2012).

Selain skala utama yang mengukur variabel penelitian, kuesioner juga menyertakan pertanyaan mengenai data demografis responden yang secara teoretis dianggap berhubungan dengan rasa kesadaran maupun kesejahteraan psikologis, seperti jenis kelamin, usia, kondisi ekonomi dan keluarga, pendidikan, pengalaman meditasi, serta keikutsertaan dalam organisasi.

\section{Skala Rasa Kesadaran: Five Facet Mindfulness Questionnaires (FFMQ)}

Skala ini disusun oleh Baer, et.al (2006) yang telah diadaptasi oleh Fourianalistyawati, Listiyandini, dan Fitriana (2016). Skala ini terdiri dari 39 item dengan menggunakan skala likert yang terdiri dari lima pilihan jawaban (tidak pernah, jarang, sekali-sekali, sering, dan sangat sering sekali). Skala FFMQ menggunakan pengukuran berdasarkan lima dimensi utama rasa kesadaran, yaitu bertindak secara sadar, mengamati, menggambarkan, tidak menghakimi pengalaman internal, dan tidak reaktif terhadap pengalaman internal. 
Uji reliabilitas dan validitas didasarkan dari uji coba terpakai pada 200 orang partisipan. Berdasarkan uji analisa item menggunakan teknik korelasi itemtotal, ditemukan bahwa pada item-item dimensi 'menggambarkan' dan 'tidak menghakimi pengalaman internal' memiliki $\mathrm{r}=0,508-0,633$. Pada dimensi 'bertindak secara sadar' dan 'mengamati' terdapat 1 item yang dihapus pada masing-masing dimensi. Pada dimensi 'tidak bersikap reaktif terhadap pengalaman internal', ditemukan tiga buah item yang kurang berfungsi dengan baik karena memiliki $\mathrm{r}<$ 0,2 . Standar sebuah item dianggap valid dan layak digunakan adalah jika memiliki koefisien korelasi di atas 0,2 (Nisfianoor, 2009). Berdasarkan hasil analisa korelasi item-total ini, terdapat hanya 34 item yang diputuskan untuk digunakan karena item memiliki $r>0,2$ sehingga dianggap layak dan sangat mendeskripsikan konstruk rasa kesadaran.

Menurut Sunjoyo (2013) bahwa nilai reliabilitas yang baik untuk digunakan sebagai instrumen pengambilan data penelitian adalah $>0,6$. Dari 34 item, alat ukur FFMQ memiliki nilai reliabilitas $\alpha=0,503-0,840$. Oleh karena itu, dapat disimpulkan bahwa skala FFMQ memiliki nilai reliabilitas yang baik, sehingga dapat digunakan sebagai instrumen pengambilan data penelitian.

\section{Skala Kesejahteraan Psikologis: Psychological Well-being Scale (SPWB)} Alat ukur kesejahteraan psikologis yang digunakan adalah scale of psychological well-being (SPWB). Skala aasli SPWB terdiri dari 42 item dan menggunakan pengukuran berdasarkan enam dimensi utama kesejahteraan psikologis yaitu penerimaan diri, hubungan positif dengan orang lain, kemandirian, penguasaan lingkungan, tujuan hidup dan pertumbuhan pribadi. Dalam penelitian ini, skala yang digunakan berupa skala likert dari rentang 1-6.

Pengujian reliabilitas dan validitas alat ukur kesejahteraan psikologis adalah melalui uji coba terpakai kepada 200 mahasiswa. Berdasarkan pada uji analisa item alat ukur SPWB yang terdiri dari 42 item hasil yang didapatkan terdapat beberapa item yang tidak valid karena memiliki nilai $<0,2$ diantaranya item 2,8 , 36 , dan 41, sehingga hanya 38 item yang digunakan dalam proses analisa data.Skala SPWB yang terdiri dari 38 item memiliki nilai reliabilitas berkisar antara $\alpha=0,617$ 0,755 pada setiap dimensi.

\section{Teknik Analisa Statistik}

Untuk penelitian ini, peneliti menggunakan model analisis uji regresi ganda. Analisis regresi berganda dilakukan untuk memprediksikan perubahan nilai variabel terikat, bila dua atau lebih variabel bebas sebagai faktor prediktor dimanipulasi (Sugiyono, 2012).

\section{ANALISIS \& HASIL}

\section{Deskripsi Rasa kesadaran}

Berikut ini gambaran rasa kesadaran berdasarkan skala likert 1-5:

Tabel 1. Gambaran Rasa Kesadaran

\begin{tabular}{ccccc}
\hline Dimensi & Min & Max & M & SD \\
\hline Bertindak sadar & 1,14 & 4,71 & 2,90 & 0,80 \\
Mengamati & 2,00 & 5,00 & 3,33 & 0,58 \\
Menggambarkan & 1,25 & 4,63 & 3,18 & 0,68 \\
Tidak reaktif & 2,00 & 4,75 & 3,31 & 0,57 \\
$\quad$ Tidak & 1,13 & 4,00 & 2,58 & 0,64 \\
menghakimi & & & & \\
\hline
\end{tabular}

Tabel 1 di atas menunjukan gambaran rerata pada setiap dimensi rasa kesadaran. Pada hasil perhitungan rerata, dimensi rasa kesadaran yang paling tinggi ada pada dimensi mengamati $(\mathrm{M}=3,33, \mathrm{SD}=0,58)$, dan paling rendah adalah pada dimensi tidak menghakimi pengalaman internal $(\mathrm{M}=2,58, \mathrm{SD}=0,64)$. 


\section{Deskripsi Kesejahteraan Psikologis}

Di bawah ini merupakan gambaran kesejahteraan psikologis partisipan ditinjau dari skala likert 1-6:

Pada hasil perhitungan rerata pada tabel 2, dimensi kesejahteraan psikologis yang paling tinggi pada dimensi tujuan hidup $(\mathrm{M}=4,35, \quad \mathrm{SD}=0,91) \quad$ dan paling rendah pada dimensi penguasaan lingkungan $(\mathrm{M}=3,60, \mathrm{SD}=0,79)$.

\section{Uji Asumsi Klasik}

Uji normalitas dilakukan untuk melihat apakah data penelitian memiliki nilai residual yang berdistribusi normal. Uji normalitas yang digunakan dalam penelitian ini adalah uji Kolmogorov-Smirnov yang membandingkan distribusi data dengan distribusi normal. Data dinyatakan berdistribusi normal apabila nilai signifikansi menunjukkan $\mathrm{p}>0,05$. Ditemukan bahwa residual berdistribusi normal.

Kemudian, uji linearitas dilakukan untuk melihat adanya hubungan yang linear atau garis lurus antara variabel bebas dan variabel terikat. Uji linear yang digunakan dalam penelitian ini adalah uji Test for Linearity. Data ditentukan linear apabila nilai sig (p) menunjukkan $\mathrm{p}>0,05$. Peneliti melakukan uji linieritas terhadap rasa kesadaran dengan tiap dimensi kesejahteraan psikologis. Dimensi kesejahteraan psikologis kemandirian dan pertumbuhan pribadi membentuk hubungan yang linier dengan tiap dimensi rasa kesadaran ( $p>0.05)$. Pada dimensi penerimaan diri, dimensi bertindak secara sadar dan menggambarkan tidak membentuk hubungan yang linier dengan penerimaan diri $(\mathrm{p}<0.05)$. Begitu juga tidak ditemukan hubungan linear $(p<0.05)$ pada dimensi hubungan positif dengan orang lain dengan dimensi mengamati, dimensi penguasaan lingkungan dengan dimensi menggambarkan, serta dimensi tujuan hidup dengan dimensi bertindak secara sadar.

\section{Hasil Analisa Utama \\ Pengaruh Rasa Kesadaran terhadap Kesejahteraan Psikologis Mahasiswa}

Pada bagian ini peneliti melakukan

Tabel 2. Gambaran Kesejahteraan Psikologis

\begin{tabular}{ccccc}
\hline Dimensi & Min & Max & M & SD \\
\hline Penerimaan Diri & 1,67 & 6,00 & 4,01 & 0,88 \\
Hubungan Positif & 1,00 & 6,00 & 4,19 & 0,89 \\
Kemandirian & 2,00 & 6,00 & 3,79 & 0,83 \\
Penguasaan & 1,80 & 5,60 & 3,60 & 0,79 \\
Tujuan Hidup & 1,50 & 6,00 & 4,35 & 0,91 \\
Pertumbuhan & 2,86 & 5,86 & 4,23 & 0,67 \\
\hline
\end{tabular}

analisis uji regresi ganda untuk melihat apakah setiap dimensi IV berperan secara signifikan terhadap setiap dimensi DV. IV dalam penelitian ini yaitu rasa kesadaran yang memiliki 5 dimensi yaitu bertindak secara sadar, mengamati, menggambarkan, tidak bersikap reaktif terhadap pengalaman internal, dan tidak menghakimi pengalaman internal. Selanjutnya, DV dalam penelitian ini adalah kesejahteraan psikologis yang memiliki 6 dimensi, yaitu penerimaan pribadi, hubungan positif dengan orang lain, kemandirian, penguasaan lingkungan, tujuan hidup, dan pertumbuhan pribadi.

Uji pertama adalah mengenai pengaruh rasa kesadaran terhadap penerimaan diri. Hasil regresi menunjukkan bahwa seluruh dimensi rasa kesadaran secara signifikan dapat menjelaskan 9,5\% varians dari dimensi penerimaan diri $\left(\mathrm{R}^{2}=0,095, \quad \mathrm{~F}=6,864, \quad p<0,01\right)$. Namun, ditemukan bahwa hanya skor mengamati $(\beta=0,246, p<0,01)$ dan tidak menghakimi pengalaman internal $(\beta=0,259, \quad p<0,01)$ yang memiliki kontribusi signifikan dalam memprediksi penerimaan diri. Untuk dimensi tidak bersikap reaktif terhadap pengalaman internal tidak dapat memprediksi secara signifikan $(\beta=0,097$, $p=0,188$, n.s), begitu juga dengan bertindak secara sadar, dan menggambarkan, juga tidak berkontribusi signifikan terhadap penerimaan diri.

Berikutnya adalah hasil uji pengaruh rasa kesadaran terhadap hubungan 
positif dengan orang lain. Ditemukan bahwa seluruh dimensi rasa kesadaran hanya dapat menjelaskan $2,6 \%$ varians dari dimensi hubungan positif dengan orang lain sehingga tidak signifikan $\left(\mathrm{R}^{2}=0,026\right.$, $\mathrm{F}=1,300, p$ 0,271). Ditemukan bahwa skor pada tiap dimensi rasa kesadaran, bertindak secara sadar $(\beta=0,112, \quad p=0,248, \quad n . s)$, menggambarkan $(\beta=0,017, p=0,842, n . s)$, tidak bersikap reaktif terhadap pengalaman internal $(\beta=0,058, p=0,457$, n.s $)$, dan tidak menghakimi pengalaman internal $(\beta=0,065$, $p=0,471$, n.s) tidak dapat memprediksi hubungan positif dengan orang lain secara signifikan.

Untuk dimensi kemandirian, hasil regresi menunjukkan bahwa seluruh dimensi rasa kesadaran hanya dapat menjelaskan $4,4 \%$ varians dari dimensi kemandirian sehingga ditemukan tidak signifikan secara statistik $\left(\mathrm{R}^{2}=0,044\right.$, $\mathrm{F}=1,799, p$ 0,115). Ditemukan bahwa skor pada tiap dimensi rasa kesadaran, yaitu mengamati $(\beta=0,135, \quad p=0,072, \quad n . s)$, menggambarkan $(\beta=0,084, p=0,315$, n.s $)$, tidak bersikap reaktif terhadap pengalaman internal $(\beta=0,109, p=0,169$, n.s $)$, dan tidak menghakimi pengalaman internal $(\beta=0,067$, $p=0,455$, n.s), dan bertindak secara sadar tidak dapat memprediksi kemandirian secara signifikan.

Pada dimensi penguasan lingkungan, hasil regresi menunjukkan bahwa seluruh dimensi rasa kesadaran berkontribusi secara efektif dan signifikan sebesar $10,3 \%$ pada varians dari dimensi penguasaan lingkungan $\quad\left(\mathrm{R}^{2}=0,103\right.$, $\mathrm{F}=5,627, \quad p<, 001)$. Namun, ditemukan bahwa hanya dimensi mengamati $(\beta=0,282$, $p<0,01)$ yang memiliki kontribusi signifikan dalam memprediksi penguasaan lingkungan. Untuk dimensi bertindak secara sadar $(\beta=0,097, \quad p=0,245, \quad n . s)$, tidak bersikap reaktif terhadap pengalaman internal $(\beta=0,031, p=0,676$, n.s $)$, dan tidak menghakimi pengalaman internal $(\beta=0,196$, $p=0,025$, n.s), tidak dapat memprediksi penguasaan lingkungan secara signifikan.

Untuk dimensi tujan hidup, hasil regresi menunjukkan bahwa seluruh dimensi rasa kesadaran hanya dapat menjelaskan $0,9 \%$ varians dari dimensi tujuan hidup sehingga tidak signifikan $\left(\mathrm{R}^{2}=0,009, \quad \mathrm{~F}=0,467, \quad p=0,760>0,05\right)$. Ditemukan bahwa skor pada tiap dimensi rasa kesadaran, yaitu mengamati $(\beta=0,027$, $p=0,719$, n.s $)$, menggambarkan $(\beta=0,097$, $p=0,198, \quad$ n.s), tidak bersikap reaktif terhadap pengalaman internal $(\beta=-0,002$, $p=0,977$, n.s) dan tidak menghakimi pengalaman internal $(\beta=-0,000, p=0,997$, n.s), dan bertindak secara sadar tidak dapat memprediksi tujuan hidup secara signifikan.

Kemudian untuk dimensi pertumbuhan pribadi, hasil regresi menunjukkan bahwa seluruh dimensi rasa kesadaran hanya dapat menjelaskan 1,9\% varians dari dimensi pertumbuhan pribadi sehingga dianggap tidak signifikan $\left(\mathrm{R}^{2}=0,019, \quad \mathrm{~F}=0,760, \quad p=0,579>0,05\right)$. Ditemukan bahwa skor pada tiap dimensi rasa kesadaran, bertindak secara sadar $(\beta=0,056, \quad p=0,566, \quad$ n.s $), \quad$ mengamati $(\beta=0,058, p=0,442, \mathrm{n} . \mathrm{s})$, menggambarkan $(\beta=0,059, \quad p=0,484$, n.s), tidak bersikap reaktif terhadap pengalaman internal $(\beta=0,078, \quad p=0,333, \quad$ n.s $), \quad$ dan tidak menghakimi pengalaman internal $(\beta=$ 0,013, $p=0,886, \quad$ n.s) tidak dapat memprediksi pertumbuhan pribadi secara signifikan.

Dengan demikian, hasil analisa regresi menunjukkan bahwa rasa kesadaran berkontribusi pada beberapa dimensi kesejahteraan psikologis mahasiswa. Dalam hal ini, rasa kesadaran dapat memprediksi secara signifikan kesejahteraan psikologis mahasiswa pada dimensi penerimaan diri dan penguasaan lingkungan.

\section{DISKUSI}

Hasil dari penelitian ini adalah rasa kesadaran berperan secara signifikan terhadap dua dimensi kesejahteraan psikologis mahasiswa. Dimensi kesejahteraan psikologis mahasiswa yang bisa diprediksi oleh rasa kesadaran yaitu, dimensi penerimaan diri sebesar $9,5 \%$ dan penguasaan lingkungan sebesar $10,3 \%$. 
Berdasarkan hasil analisis, dimensi rasa kesadaran yang dapat memprediksi dimensi penerimaan diri pada kesejahteraan psikologis adalah dimensi mengamati. Mengamati, menurut penemuan Baer et al (2006), adalah menyadari atau melibatkan diri dengan pengalaman internal maupun eksternal seperti sensasi, kognisi, dan emosi. Individu yang memiliki nilai tinggi pada dimensi penerimaan diri, merasa puas terhadap dirinya dan selalu mampu melihat kelebihan yang ada pada dirinya (Ryff dalam Wells, 2010). Hurlock (dalam Wibowo, 2010) mengatakan bahwa individu yang memiliki penerimaan diri, mampu mengenali kelebihan dan kekurannya, individu mampu menerima dirinya dan memiliki keyakinan diri, memiliki penilaian yang realistis serta merasa puas dengan dirinya sendiri tanpa ada keinginan untuk menjadi orang lain. Oleh karena itu, apabila mahasiswa menyadari dan mampu melibatkan diri dengan pengalaman internal dan eksternal yang dialaminya secara sadar, maka mahasiswa mampu mengenali kelebihan dan kekurangannya, mampu menerima dirinya dan memiliki keyakinan diri, memiliki penilaian yang realistis serta merasa puas dengan dirinya sendiri tanpa ada keinginan untuk menjadi orang lain.

Dimensi rasa kesadaran lainnya yang memiliki kontribusi pada dimensi penerimaan diri adalah tidak menghakimi pengalaman internal. Tidak menghakimi pengalaman internal dapat diartikan sebagai mengambil sikap non-evaluatif atau tanpa adanya penilaian terhadap pikiran-pikiran yang ada dalam diri (Baer et al., 2006). Mahasiswa yang tidak bersifat menghakimi dirinya akan mampu menerima dirinya dengan baik, merasa puas dengan dirinya, serta tidak memiliki keinginan untuk menjadi orang lain. Sebagai contoh mahasiswa yang menerima secara sadar atas hasil dari prestasi belajarnya serta tidak merasa rendah diri atau harga dirinya terjatuh hanya karena hal tersebut, maka akan lebih mampu menerima dirinya seutuhnya selayaknya manusia biasa.
Rasa kesadaran, khususnya pada dimensi mengamati juga memiliki kontribusi signifikan terhadap penguasaan lingkungan. Individu yang memiliki kemampuan untuk menguasai lingkungan adalah mereka yang mampu mengendalikan diri dengan lingkungan sekitar, mengembangkan potensi yang ada di dalam diri, dan memiliki kemampuan dalam menggunakan kesempatan dan peluang yang ada (Ryff dan Keyes dalam Wells, 2010). Ryff (1995) mengatakan bahwa individu yang memiliki penguasaan lingkungan yang baik adalah individu yang mampu mengatur aktivitas eksternal yang kompleks, menggunakan kesempatan di sekitar dengan efektif, dan mampu memilih atau menciptakan konteks yang sesuai dengan kebutuhan. Saat mahasiswa mampu menyadari atau melibatkan dirinya dalam pengalaman internal ataupun eksternal sebagai mahasiswa, maka ia akan lebih mudah menguasai lingkungannya. Mahasiswa lebih mampu mengendalikan diri ketika berhadapan dengan dosen ataupun teman-temannya, mampu untuk mengembangkan potensi di dalam dirinya, serta mampu menggunakan kesempatan dan peluang yang ada selama menjadi mahasiswa.

Hasil penelitian menunjukkan bahwa rasa kesadaran tidak memprediksi hubungan positif dengan orang lain, kemandirian, pertumbuhan diri, dan tujuan hidup. Hal ini menujukkan bahwa adanya faktor-faktor lain yang berkontribusi terhadap terhadap kesejahteraan psikologis pada dimensi ini. Perlu adanya penelitian lebih lanjut untuk mengkaji mengenai hal tersebut.

Pada hasil perhitungan rerata pada tiap dimensi kesejahteraan psikologis didapatkan rerata rendah pada penguasaan lingkungan dibandingkan lainnya. Dengan demikian, diantara dimensi kesejahteraan psikologis yang lain, mahasiswa masih mengalami kesulitan dalam dimensi penguasaan lingkungan. Artinya, mahasiswa belum terlalu mampu menguasai dan berkompetensi dalam 
mengatur lingkungannya, menggunakan kesempatan yang ada, serta tidak mampu mengontrol aktivitas di luar dirinya dengan baik. Mahasiswa masih kurang mampu mengendalikan sumber stress yang berkaitan dengan akademik dan kurang mampu mengendalikan konflik yang dihadapi. Namun dari hasil penelitian juga ditemukan bahwa dengan adanya rasa kesadaran pada mahasiswa, mahasiswa dapat memiliki penguasaan lingkungan yang lebih baik. Dengan kata lain, apabila mahasiswa mampu sadar dan memberi perhatian dengan keberadaannya, maka mahasiswa menjadi lebih mampu menguasai dan berkompetensi dalam lingkungkan.

Pada hasil perhitungan kesejahteraan psikologis, didapatkan ratarata tinggi pada dimensi tujuan hidup dan pertumbuhan pribadi, sedangkan dimensi penguasaan lingkungan dan kemandirian termasuk dalam rata-rata yang rendah. Penemuan ini dapat dijelaskan oleh pendapat Ryff. Penelitian mengenai faktor usia terhadap kesejahteraan psikologis yang dilakukan Ryff (1989) menemukan hasil bahwa terdapat perbedaan kesejahteraan psikologis pada individu dalam rentang usia tertentu. Hasil yang ditemukan dalam penelitian Ryff (1989) adalah dimensi penguasaan lingkungan dan kemandirian akan bertambah seiring dengan bertambahnya usia. Sebaliknya, tujuan hidup dan pertumbuhan diri semakin berkurang.

Pada penelitian ini, peneliti menduga bahwa mahasiswa memiliki kemandirian yang tidak terlalu tinggi karena mahasiswa masih belum mampu menguasai lingkungan dengan baik. Apabila mahasiswa mampu menguasai lingkungannya dengan baik, ia mampu tumbuh secara mandiri. Sebagai contoh, sebagian besar mahasiswa masih tergantung secara finansial dengan orang tuanya, hal ini yang membuat mahasiswa belum mampu tumbuh secara mandiri.

Faktor lainnya yaitu tingkat
pendidikan merupakan faktor yang

berpengaruh terhadap kesejahteraan psikologis yang dimiliki individu. Individu yang memiliki tingkat pendidikan yang lebih baik maka, memiliki kesejahteraan psikologis yang lebih baik juga. Dalam penelitian ini tingkat pendidikan mayoritas partisipan merupakan lulusan SMA sederajat yang melanjutkan studi ke perguruan tinggi. Hal ini menyebabkan tidak semua dimensi dalam kesejahteraan psikologis berada pada kategori tinggi, khususnya pada dimensi penguasaan lingkungan dan kemandirian.

Pada hasil perhitungan rerata pada tiap dimensi pada rasa kesadaran didapatkan rata-rata rendah pada dimensi tidak menghakimi pengalaman internal yaitu. Padahal, tidak menghakimi pengalaman internal merupakan salah satu dimensi rasa kesadaran yang memberikan kontribusi pada dimensi penerimaan diri. Erikson (dalam Ryff, 1989) berpendapat bahwa penerimaan diri juga melibatkan penerimaan akan masa lalu tentang keberhasilan dan kegagalan yang dialami individu. Oleh karena itu, apabila mahasiswa ingin memiliki penerimaan diri yang baik maka mahasiswa harus mampu menerima dirinya secara sadar tanpa mengakimi secara berlebihan mengenai apa yang telah terjadi. Apabila mahasiswa mengakimi diri sendiri mengenai apa yang dilakukannya tanpa adanya penerimaan atas masa lalu yang tidak berhasil, hal ini dapat menyebabkan menurunnya penerimaan diri pada mahasiswa.

Pada hasil perhitungan rerata pada tiap dimensi rasa kesadaran juga didapatkan rata-rata rendah pada dimensi bertindak secara sadar. Peneliti menduga bahwa kemampuan bertindak secara sadar pada mahasiswa belum optimal dikarenakan mereka tidak mampu memberikan perhatian secara penuh dan sadar atas aktivitas yang ia lakukan. Berbagai tuntutan akademik maupun non-akademik yang datang bersamaan, membuat mahasiswa dituntut untuk mampu mengerjakan beberapa tugas juga dalam waktu yang bersamaan sehingga mahasiswa kurang memiliki bertindak 
secara sadar. Hal ini sejalan dengan penelitian yang dilakukan Kementerian Kesehatan di Amerika juga mengatakan mahasiswa memiliki banyak sumber stress, antara lain adalah tekanan akademis, perubahan lingkungan dengan tanggung jawab baru, serta mempersiapkan kehidupan setelah kuliah (National Health Ministries, 2006).

Pada hasil perhitungan rerata pada tiap dimensi pada rasa kesadaran didapatkan rata-rata tinggi pada dimensi mengamati. Artinya, partisipan mahasiswa dalam penelitian ini sudah cukup mampu menyadari dan mengamati pengalaman internal dan eksternalnya. Dengan kata lain, mahasiswa cukup mampu menyadari dan mampu melibatkan diri dengan apa yang terjadi terhadap sekitarnya. Dalam konteks kehidupan mahasiswa sebagai contoh mereka mau melibatkan diri dalam organisasi dan mampu melakukan pengabdian masyarakat yang baik. Hal ini didukung oleh hasil penelitian bahwa partisipan mahasiswa pada penelitian ini rata-rata mengikuti organisasi yang ada di universitas maupun di luar universitas

\section{SIMPULAN}

Hasil dari penelitian menunjukkan bahwa rasa kesadaran berperan secara positif dan signifikan terhadap dua dimensi kesejahteraan psikologis, yaitu dimensi penerimaan diri dan penguasaan lingkungan. Dimensi yang berpengaruh terhadap penerimaan diri adalah mengamati dan tidak menghakimi pengalaman internal, sedangkan dimensi yang berpengaruh terhadap penguasaan lingkungan adalah mengamati.

\section{SARAN}

Untuk penelitian selanjutnya, perlu dilakukan perbaikan dan pengembangan dalam beberapa hal. Penelitian berikutnya perlu melakukan teknik sampling yang lebih ideal, misalnya dengan menggunakan quota sampling atau bahkan probability sampling. Kelemahan lainnya, dalam penulisan item-item dalam alat ukur tata bahasanya harus lebih diperhatikan lagi, karena saat peneliti memberikan kuesioner langsung kepada partisipan, ada beberapa partisipan yang menanyakan terkait bahasa dalam penulisan item. Selanjutnya, pada penelitian ini faktor-faktor yang diteliti tidak semuanya berkaitan, peneliti lain yang akan meneliti tentang kesejahteraan psikologis sebaiknya mengaitkannya atau memperhatikan faktor lain yang mungkin terkait. Selanjutnya, pada penelitian ini menggunakan uji coba terpakai dikarenakan beberapa alasan tertentu. Untuk penelitian selanjutnya diharapakan tidak menggunakan uji coba terpakai. Pada penelitian selanjutnya diharapkan dapat menggali atau meneliti pada populasi partisipan yang memiliki jejang pendidikan lebih tinggi dari mahasiswa S1. Hal ini dikarenakan jenjang pendidikan individu mempengaruhi baik atau tidaknya kesejahteraan psikologis pada individu, karena semakin tinggi jenjang pendidikannya semakin baik kesejahteraan psikologis yang dimiliki.

\section{Implikasi Penelitian}

Dari hasil penelitian diketahui bahwa untuk meningkatkan penerimaan diri dan penguasaan lingkungan mahasiswa, maka mahasiswa perlu lebih memiliki rasa kesadaran, dengan cara melibatkan diri dalam pengalaman internal maupun eksternal serta tidak bersikap menghakimi diri sendiri. Rasa kesadaran sendiri dapat ditingkatkan dengan berbagai cara, misalnya dengan mengikuti pelatihan meditasi, yoga, ataupun membiasakan diri berlatih untuk selalu menjalani aktivitas rutin, seperti mandi, makan, belajar, dan berinteraksi dengan orang lain dengan penuh kesadaran. Dengan memaksimalkan diri untuk terlibat penuh dalam pengalaman dan perasaan yang muncul, tidak menghakimi diri sendiri, dan menerima diri apa adanya, mahasiswa akan memiliki penerimaan diri dan penguasaan lingkungan yang baik. 


\section{DAFTAR PUSTAKA}

Baer, R. A., Smith, G. T., Hopkins, J., Krietemeyer, J., \& Toney, L. (2006). Using self-report assessment methods to explore facets of mindfulness. Assessment, 13(1), 27-45.

Blau, G.M. (1996). Adolescent suicide and depression. Dalam B.M. Blau \& Thomas P. Gultotta (Ed.), Adolescent dysfuctional behavior: Causes, interventions, and prevention. London: Sage Publication.

Brebahama, A., \& Listiyandini, R. A. (2016). Gambaran Tingkat Kesejahteraan Psikologis Penyandang Tunanetra Dewasa Muda. MEDIAPSI, 2(1), 1-10.

Brown, K.W., \& Ryan, R.M. (2003). The benefit of being present: mindfulness and it's role in psychological well being. Journal of Personality \& Social Psychology, Vol. 84, No. 4, 822-848.

Fadli, F. (2012). Hubungan antara dukungan sosial dengan psychological well being pada mahasiswa. Skripsi. Malang: Universitas Muhammadiyah Malang

Fajrina, A.D., \& Rosiana, D. (2015). Hubungan flow dengan psychological well being mahasiswa psikologi unisba yang aktif organisasi. Skripsi. Bandung: Fakultas Psikologi Universitas Islam Bandung.

Finucane, A., \& Mercer, S. W. (2006). An exploratory mixed methods study of the acceptability and effectiveness of mindfulness-based cognitive therapy for patients with active depression and anxiety in primary care. $B M C$ psychiatry, 6(1), 14.

Fourianalistyawati, E., Listiyandini, R. A., \& Fitriana, T. S. (2016). Hubungan Mindfulness dan Kualitas Hidup Orang Dewasa. Prosiding Forum Ilmiah Psikologi Indonesian (FIPI). Fakultas
Psikologi Universitas Tarumanegara. Diunduh dari researchgate.net pada 12 Oktober 2017.

Furr, S.R., Mc Connel, G.N., Westefeld, J.S., \& Jenkins, J.M. (2001). Suicide and depression among college students: A decade late. Professional Psychology: Research and Pratice, 32, 97-100.

Hariyanto, A.D. (2010). Prevelensi depresi dan faktor yang mempengaruhi pada mahasiswa fakultas kedokteran universitas katolik indonesia atma jaya angkatan 2007. Karya Tulis Ilmiah Kedokteran. Jakarta.

Ismail, R.G., \& Indrawati, E.S. (2013). Hubungan dukungan sosial dengan psychological well being pada mahasiswa stie dharmaputera program studi ekonomi manajemen semarang. Jurnal Fakultas Psikologi Universitas Diponegoro Vol 2, No. 4.

Kabat-Zinn, J. (1990). Full catastrophe living: Using the wisdom of your body and mind to face stress, pain, and illness. New York, NY: Dell Publishing.

Lau, M.A., \& McMain, S.F. (2005). Integrating mindfulness meditation with cognitive and behavioral therapies: The challengge of combining acceptance and change based strategies. The Canadian Journal of Psychiatry, Vol. 50, No. 13, 863-869.

Michael, et.al. (2006). Depression among college students: trends in prevalence and treatment seeking. Counseling and Clinical Psychology Journal: Psychological Publishing

National Health Ministries. (2006). Stress $\&$ the college students. USA.

Nisfiannoor, M. (2009). Pendekatan statistika modern untuk ilmu sosial. Jakarta: Salemba Humanika.

Papalia, D.E., Olds, S.W., \& Feldman, R.D. (2008). Human development (Psikologi 
Perkembangan edisi kesebilan). Jakarta: Kencana.

Pennebaker, J.W., Colder, M., \& Sharp, L.K. (1990) Accelerating the coping process. Journal of Personality and Social Psychology, 58, 528-537.

Putri, F.O. (2012). Hubungan antara gratitude dan psychological well-being pada mahasiswa. Skripsi. Depok: Fakultas Psikologi Universitas Indonesia.

Ryff, C. D. (1989). Happines is everything, or is it? Explorations on the retaining of psychological well-being. Journal of personality and social psychology, 1069-1081.

Ryff, C. D. (1995). The stucture of psychological well-being revisited. Journal of personality and social psychology, 719-727.

Smolak, L. (1993). Adult development. New Jersey : Prentice-Hall, Inc.

Sugiyono. (2012). Statistika untuk Penelitian. Bandung: Penerbit Alfabeta.

Voitkane, S. (2001). First year student social adjustment to university. http://www.ispaweb.org/en/olloquium/n yborg\%20Presentation/voitkane.htm.

Diunduh pada 18 Oktober 2015

West, A.M (2008). Mindfulness and wellbeing in adolescence: An exploration of four mindfulness measures with an adolescent sample. Proquest Dissertation \& Theses.

Wibowo. (2010). Psikologi untuk Pengembangan Diri. Bandung: Widya Padjadjaran. 